\title{
WAYS TO IMPROVE EFFICIENCY OF FUTURE NURSES' ETHICAL EDUCATION
}

\section{Bilichenko Oleksandr ${ }^{1}$}

\section{DOI: https://doi.org/10.30525/978-9934-571-89-3_9}

The conceptual approach to design the process of forming professional ethics among the students of the medical college is focused on the comprehensive use of the possibilities of the medical college educational system, individuals of the given system, and the requirements of state policy in the field of training future specialists and the specifics of medical workers' functions.

We have identified ways to increase the effectiveness of ethical training of future nurses with theoretical and applied components in the projected process. These ways include the formation of the ethical outlook of future medical workers by enriching the ethical content of their life through the interaction of all individuals in the educational system of the medical college; practical orientation of methods, forms, methods and means of forming the professional ethics of future physicians in the educational process of medical college; the use of educational potential of socialprofessional macro-environment, peculiarities of professional activity of specialists of middle-level medical profile; the implementation of system control and correction of the ongoing activities.

The strategy of forming a professional ethics for students reflects the general prospects and plan for achieving the goals set in the process of educating future healthcare professionals. It is based on the fundamental principles of a person-oriented paradigm of education and directs students to the formation of professional ethics.

According to the principles of strategy, tactics determines the content of the process of forming professional ethics of future nurses and a set of measures at each stage of the research and experimental work. It is established on a legal basis, due to the scientific recommendations [2]. Besides, tactics takes into account the actual results of the process of forming the professional ethics of future medical workers.

The technique of forming professional ethics is characterized by a set of methods, operations and other actions of the educational process' individuals (students and teachers) who use methodological tools for achieving the goals. Their complex, interconnected application has a systematic and methodically consistent features [5].

The forming professional ethics among future medical workers is implemented in the educational process of the medical college and consists of a number of stages (analytical-diagnostic, organizational-motivational, content-activity, evaluativeproductive, effective-corrective), each of which, being a component of a holistic educational system, pursues a certain goal and has its own content.

It should be noted that each of the stages concerning the process of forming the professional ethics of future nurses is directly related to the components of the

\footnotetext{
${ }^{1}$ Vinnytsia Mykhailo Kotsiubynskyi State Pedagogical University, Ukraine 
developed model. Thus, the organizational-motivational and analytical-diagnostic stages include the communicative-activity component, which, in it's turn, is reflexive-evaluative and productive-corrective.

The aim of organizational and motivational stage is the development of positive motivation, interest and awareness of the necessity to have the professional ethics formed among the students of medical college. There are some tasks that can be solved at this stage. To begin with, it shows the social and professional importance of professional ethics to the future nurses. Furthermore, it acquaints students with a complex of moral and ethical qualities. It also makes students to be aware of the presence or absence of these qualities in their own personality and in this way starts their self-education. Lastly, it sets up to succeed.

The main task of the functional-practical stage is to use methodical tools directed to form professional ethics in the educational process among students of medical college.

Formation of professional ethics among the students of medical college is a complex, multifaceted, dynamic process in which the entire teaching staff of the school is involved. The success of this process is ensured, first of all, by the planning, scientific nature, consistency, creative nature, profound meaning and effectiveness of the ongoing activities, creating conditions for their favorable perception by students, with the active participation of future medical workers themselves. The important role in this process is given to special methods forming professional ethics, which allow to organize the ethical training of future healthcare professionals in the methodical and expedient way in educational process of the medical college.

The methods of the professional ethics' formation (diagnostic, purpose-oriented, organizational, motivational, communicative, formative, control-analytical, evaluative, coordinative-corrective) are considered as pedagogical functions' means of realization at each stage of experimental work. Diagnostic methods are directed to visual, verbal, practical study of students in order to gain more information about their suitability to professional and ethical requirements. They analize the effectiveness of professional training process to develop future medical nurses' skills building a professional interaction due to the deontological basis. The goal-setting group of methods includes the ranking, differentiation, personification of tasks related to the methods of realizing moral and ethical qualities concerning the nurses' professional functions' performance. Planning methods include structuring, valuation, personification, and planning of activities. They reflect the future nurses' willing to use ethical and deontological norms in the area of relations' regulation through their professional activity.

Organizational methods fall in with the collective and individual forms of work in class and extra-class time. These forms of work's task is to activate students' selfrealization in different socio-professional roles according to professional and ethical standards. Mobilizative-inducing methods involve mobilization, updating, motivation, reinforcement of meaningful mental states, activities and behavior of students. They are effective in the formation of the future nurses'professional and ethical outlook in the form of ethical views, believes, ideals, attitudes and ethical assessments. Communicative methods consist of choosing adequate positions, 
adapting relationships, preventing conflicts, developing norms of relationships, accumulation of consent, cooperation ensuring. All abovementioned methods provide skills for facilitating the process of individuals' interaction of the medical process, the ability to unite colleagues on the basis of common professional interests and professional- ethical values related to the patient's health recovery

The formative methods are responsible for students to learn the principles of medical staff's professional conduct in accordance with the professional ethics standards. The control, analytical and evaluational methods (analysis, synthesis, classification, typing, comparison, generalization, evaluation of the effectiveness of educational and professional activities) allow us to verify the course and results of using the educational potential of the social and professional environment in the medical college while developing the professional ethics of future specialists. Coordinational and corrective methods provide the choice and use of common and personalized requirements for students as future specialists. These methods allow to analyze the results of work on the formation of professional ethics among the medical college students, evaluating their own activities, correcting of achieving goals' means. Methods of improving the process of forming the professional ethics of future nurses are presented in the study of the works of scientists $[1 ; 3 ; 4]$. They highlight the specifics of building an effective interaction of medical personnel with those who need professional assistance, best practices in constructing professional and ethical relationships with all the individuals involed in treatment process, medical college students' research and experimental work.

Thus, the process of forming professional ethics for future nurses is characterized by systematic use of a set of methods and ways of interaction between the educational process' individuals (students and teachers), directed to achieving the goals.

\section{References:}

1. Agharkova A. O. (2011). Formuvannja profesijno-etychnoji kuljtury majbutnikh likariv u vyshhykh navchaljnykh zakladakh [Forming professionally ethics cultures of future doctors in higher educational establishments] (PhD Thesis), Kyiv.

2. Ghaluzjak V. M. (2016). Rozvytok profesijnoji sprjamovanosti studentiv vyshhykh medychnykh navchaljnykh zakladiv [Development of professional orientation of students of higher medical educational establishments. Vinnycja: TOV "Nilan-LTD. (in Ukrainian).

3. Jevtushenko Ju. O. (2017). Formuvannja deontologhichnoji kuljtury likariv u navchaljnovykhovnomu procesi medychnogho VNZ [Forming of deontologichnoy culture of doctors in educational - an educate process of medical higher educational establishment]. ( $\mathrm{PhD} \mathrm{Thesis}$ ), Starobiljsjk.

4. Kuznecova I.V. (2005). Pedaghoghichni umovy formuvannja empatijnoji kuljtury studentiv vyshhykh medychnykh navchaljnykh zakladiv [Pedagogical terms of forming of empatiynoy culture of students of higher medical educational establishments] (PhD Thesis), Kharkiv, Kharkivsjkyj nacionaljnyj pedaghoghichnyj universytet imeni Gh.S. Skovorody.

5. Kholkovsjka I.L. (2018). Shljakhy formuvannja partnersjkykh vidnosyn mizh vykladachem i studentamy v osvitnjomu procesi [Ways of forming of partner relations are between a teacher and students in an educational process] Proceedings of the Naukovi zapysky Vinnycjkogho derzhavnogho pedaghoghichnogho universytetu imeni M. Kocjubynsjkogho. Serija: "Pedaghoghika i psykhologhija”. Vypusk 56, Vinnycja, pp. 185-192. 